\title{
Measurement of antibodies reacting with capsular antigens of Haemophilus influenzae
}

\author{
D. C. TURK AND C. A. GREEN \\ From the Department of Microbiology, University of Newcastle upon Tyne, \\ and the Royal Victoria Infirmary, Newcastle upon Tyne
}

SYNOPSIS A simple haemagglutination procedure is described which measures antibodies that $\vec{y}$ react with capsular antigens of Haemophilus influenzae. Abnormally high antibody titres of appropri- $\omega$ ate type-specificity are common in the blood of human subjects who are known to have carried 0 capsulate strains of $H$. influenzae. It is not yet clear whether all such antibodies are due to such ${ }_{\circ}^{+}$ carriage.

A minority of strains of Haemophilus influenzae are capsulate and are divisible into six serotypes, a, b, c, $d$, e, and $f$, differing in their capsular antigens (Pittman, 1931, and later unpublished work). These antigens are substituted polysaccharides (Rosenberg, Leidy, Jaffee, and Zamenhof, 1961). The strains that cause haemophilus meningitis nearly all belong to type b, and this serotype can also cause various other acute illnesses. Capsulate strains of the other five types have only rarely been incriminated as pathogens.

Ability to measure antibody responses to capsulate strains of this species might help to solve a number of questions, including 1 , whether the high frequency of carriers of $H$. influenzae type b in the homes of children with haemophilus meningitis (Good, Fousek, Grossman, and Boisvert, 1943; Turk, 1963) is a prelude to or a consequence of the patients' infection; and, 2 , whether the non-capsulate strains that play a prominent part in the maintenance of chronic bronchitis are degraded descendents of capsulate strains, as suggested by May (1958), and are thus different from the non-capsulate strains commonly found in the upper respiratory tracts of healthy people.

Keogh, North, and Warburton (1947, 1948) described a haemagglutination technique in which red blood cells were coated with haemophilus capsular polysaccharide and then used to test the agglutinating power of sera. They grew the capsulate organisms on solid media, washed them off, extracted the polysaccharide from the washings and then exposed red cells to the extract. They used this pro- cedure to measure the type-specific antibody content $\stackrel{2}{<}$ of rabbit sera. Faunce (quoted by May, 1958) applied $\overrightarrow{0}$ it to human sera but tested only a small number of sera and obtained disappointingly low titres.

The method to be described here is simpler than that of Keogh and his colleagues. Red cells are added directly to the supernatant of a centrifuged broth culture of the appropriate serotype and are $\mathbb{Q}$ left to take up the polysaccharide for themselves. This relatively crude procedure results in type- $\bar{O}$ specific sensitization and gives higher haemagglutination titres for human sera than those obtained by Faunce.

\section{MATERIALS}

CULTURE MEDIA Levinthal's broth and Levinthal's agar $\delta$ are made according to the recommendations of Alexander (1958) apart from the substitution of oxalated for 음 defibrinated horse blood and of a locally-made meat infusion for neopeptone broth.

H. INFLUENZAE TYPING SERA Those used are obtained from two commercial sources, Messrs. Burroughs, Wellcome and Co. of London and Messrs. Hyland Laboratories of Los Angeles.

ORGANISMS Of the six capsulate strains now in regular use, those of types a, b, and e were isolated locally, those $\frac{\bar{D}}{\mathrm{D}}$ of types $\mathrm{c}$ and $\mathrm{d}$ were kindly supplied by Mr. H. Proom, and that of type $f$ came from the National Collection of Type Cultures. All form mucoid, iridescent colonies on $\bar{O}$ Levinthal's agar and give appropriate slide-agglutination $\frac{\overrightarrow{\mathbb{D}}}{\mathrm{D}}$ reactions with Burroughs, Wellcome sera and capsule- $\stackrel{\mathcal{O}}{\mathscr{Q}}$ swelling reactions with Hyland Laboratories sera, though the agglutination of type c strains by homologous 
Burroughs, Wellcome serum has in our hands always been very slow and weak.

SENSITIZING SOLUTIONS Each batch of solution is prepared by inoculating the appropriate strain into a $40 \mathrm{ml}$. or $80 \mathrm{ml}$. volume of Levinthal's broth in a screw-capped bottle. The inoculum is taken from an iridescent colony on an overnight Levinthal's agar culture. After two days' incubation at $37^{\circ} \mathrm{C}$. the broth is centrifuged to remove bacteria, and the supernatant is stored at $-20^{\circ} \mathrm{C}$.

RED BLOOD CELLS Fresh group $O$ human red cells are washed three times in saline before sensitization.

SALINE It has not been found necessary to buffer the isotonic saline used for washing and suspending the cells and for diluting the sera.

\section{METHOD}

MEASUREMENT OF SMALL VOLUMES In the paragraphs which follow, references to drops should be taken to mean those from a '50-dropper' Pasteur pipette (Morse gauge 59).

SENSITIZATION OF RED CELlS One drop of packed red cells is added to each of seven tubes, of which six contain $1 \mathrm{ml}$. volumes of the six sensitizing solutions and the seventh contains $1 \mathrm{ml}$. of Levinthal's broth. After thorough mixing of the cells with the solutions (which is essential for complete sensitization), the tubes are placed in a $37^{\circ} \mathrm{C}$. incubator for three hours. The cells are then deposited by centrifugation, washed three times in saline, and resuspended in $1.75 \mathrm{ml}$. of saline.

SERA These do not need to be inactivated. Doubling dilutions in saline are prepared by a dropping method.

THE TEST Two drops of each serum dilution are added to two drops of each cell suspension in the depressions of a Perspex haemagglutination tray, and mixed by gentle tapping and shaking. After one hour at room temperature the trays are again shaken to resuspend the cells, and haemagglutination is read with the aid of a hand lens. The titre recorded is the final dilution of the serum in the last depression in which definite, even if incomplete, haemagglutination is seen.

STANDARDIZATION OF THE TESTS Standard sensitizing solutions have been prepared by freeze-drying, in multiple small amounts, one batch of sensitizing solution for each serotype. Such preparations, when reconstituted, retain their original sensitizing potency. The potency and type-specificity of each new batch of solution are checked by testing it in parallel with its appropriate standard against both sets of commercial antisera. For any one serotype, the potency of different batches of solution has been remarkably constant. A few low-titre crossreactions with commercial sera of the wrong specificity have been observed, but these appear to have been due to incomplete specificity of some batches of sera rather than of the sensitizing solutions.

In routine use of the test, each sensitized-red-cell suspension each day is tested for agglutinability by saline and by a dilution of homologous typing serum which should just give definite agglutination.

EFFECTS OF VARIATION OF TECHNIQUE In preliminary studies, no differences were detected between the sensitizing potencies of solutions made from different bacterial strains of the same type, or of solutions made from the same strain by incubating broth cultures for various periods from two to eight days; those from 18-hour broth cultures were somewhat less potent. Varying the duration of sensitization of the cells between one half and three hours was found to affect the speed with which they were subsequently agglutinated, but not the readings obtained if the tests were allowed to stand for at least one hour; sensitization for more than three hours did not further increase the speed of agglutination. The ratio of $1 \mathrm{ml}$. of solution to 1 drop of cells was found to be a generous excess. The temperature at which sensitization was carried out made a marked difference; cells sensitized at $37^{\circ} \mathrm{C}$. were agglutinated faster and by higher serum dilutions than were those sensitized at room temperature, and only very feeble sensitization occurred at $4^{\circ} \mathrm{C}$. The volume of saline used to suspend the sensitized cells could be varied quite widely without affecting the results. The temperature at which the test itself was carried out was not observed to make any difference (within the range $4^{\circ}$ to $37^{\circ} \mathrm{C}$.) except to the amount of interference from cold agglutinins.

\section{RESULTS}

IN RELATION TO KNOWN CARRIAGE OF CAPSULATE STRAINS Antibody titres of $1: 8$ or higher against any of the six suspensions of sensitized cells have been rare in the sera from infants which have so far been examined, but more frequent in those from older children and adults. Subjects known to have carried capsulate strains tend to develop abnormally high levels of homologous antibodies, i.e., of antibodies of the same type-specificity as the organism isolated. We have examined sera from 30 such carriers, some with and some without related illnesses. Of these, three will be discussed in the next section, and three were young children whose acute infections were promptly and adequately treated with antibodies, and who showed no detectable antibody responses. In the absence of a better yardstick, the results from the remaining 24 carriers can be assessed by regarding the following titres as abnormally high or 'positive': $1: 32$ for types $b$ and c; $1: 16$ for types a and d; $1: 8$ for type f; and $1: 4$ for type e. (These were titres given by less than $20 \%$ of a series of 300 adult hospital patients who were not known to have carried capsulate strains.) On this basis, 20 of the 24 homologous titres were 'positive' as against only 26 of the 120 heterologous 
titres. This is a highly significant difference ( $\mathrm{P}$ is less than 0.001). Furthermore, there was no evidence that any of the four subjects who gave 'negative' homologous results had been exposed to a capsulate strain for more than five days before collection of the serum tested. All six serotypes were represented among the homologous 'positives'.

IN THE FAMILY OF A CHILD WITH HAEMOPHILUS MENINGITIS All of the relevant findings from this family are shown in the Table. The six serum samples obtained from the patient's mother and brother were tested simultaneously, and the order in which they had been set out on the trays was not known to the observer at the time of reading the results.

The findings suggest that the type $b$ strain of $H$. influenzae had been in the family for at least some weeks, carried first by the brother and then by the mother, before it was transmitted to K.K. himself and to his father.

The exceptionally high titre for type e found in the father's serum presumably has no relevance to the carriage of type $b$.

\section{TABLE}

RESULTS FROM THE FAMILY OF A CHILD WITH HAEMOPHILUS MENINGITIS $^{1}$

\begin{tabular}{|c|c|c|c|c|c|c|c|}
\hline \multirow[t]{2}{*}{ Subject } & \multirow[t]{2}{*}{$\begin{array}{l}\text { Serum } \\
\text { Collected on }\end{array}$} & \multicolumn{6}{|c|}{$\begin{array}{l}\text { Reciprocal of Highest } \\
\text { Serum Dilution giving } \\
\text { Agglutination }\end{array}$} \\
\hline & & $a$ & $b$ & $c$ & $d$ & $e$ & $f$ \\
\hline K.K. (aged 1 yr.) & $\begin{array}{l}29.11 .62 \\
17.12 .62 \\
31.12 .62 \\
14.1 .63\end{array}$ & - & $\begin{array}{l}- \\
- \\
-\end{array}$ & 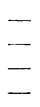 & $\begin{array}{r}- \\
8 \\
8 \\
-\end{array}$ & - & - \\
\hline Father & $30.11 .62^{2}$ & 8 & - & 8 & - & 32 & - \\
\hline Mother & $\begin{array}{l}30.11 .62^{2} \\
17.12 .62 \\
31.12 .62 \\
14.1 .63\end{array}$ & $\begin{array}{l}- \\
- \\
-\end{array}$ & $\begin{array}{r}8 \\
16 \\
16 \\
32\end{array}$ & $\begin{array}{l}8 \\
8 \\
8 \\
8\end{array}$ & $\begin{array}{r}8 \\
8 \\
8 \\
16\end{array}$ & - & $\begin{array}{l}- \\
- \\
-\end{array}$ \\
\hline Brother (aged 3 yr.) & $\begin{array}{l}30.11 .62 \\
31.12 .62\end{array}$ & $\underline{8}$ & $\begin{array}{l}64 \\
64\end{array}$ & $\overline{8}$ & $\begin{array}{l}32 \\
32\end{array}$ & - & - \\
\hline
\end{tabular}

- no agglutination at a dilution of $1: 8$

${ }^{1}$ K.K. was admitted to hospital on 29 November 1962 with meningitis of four days' duration. $H$. influenzae type b was grown from his cerebrospinal fluid.

${ }^{2}$ Nose and throat swabs were collected from the parents and the brother on the same dates as the serum samples, but only those from the parents on 30 November 1962 yielded $H$. influenzae type $b$.

\section{DISCUSSION}

RELIABILITY The method has presented few problems, the end-points are easy to read, and the reproducibility compares favourably with that $\frac{0}{\overrightarrow{5}}$ many serological tests in common use. The only other methods of measuring antibodies to $H \overrightarrow{H_{0}}$ influenzae capsular antigens hitherto reported as applicable to human sera are those used by Woof and her associates (Wood, Buddingh, and Abbergerw⿳ 1954; Sell, 1960). They employed suspensions oळ capsulate bacilli for agglutination and capsule swelling tests; and from their description it is cleaf that the results were not easy to read. Our procedure has the advantage of using stable and easily store屯 sensitizing solutions instead of organisms. It is alsఱ possible, though not certain, that only the capsula⿳亠丷厂 and not the somatic $H$. influenzae antigens are present in the final tests.

NATURE OF THE ANTIBODIES MEASURED It is cleaß from the results quoted above that some of the antibodies detected were formed in response to contact with capsulate strains of $H$. influenzae. BuE this may not be the whole story. Antibodies to typer $c$ and $d$ have been found in many of the sera tested $\vec{c}$ whereas strains of these serotypes are rare in oug experience here, as well as in surveys elsewhere (e.g., Dawson and Zinnemann, 1952, in Leedso Masters, Brumfitt, Mendez, and Likar, 1958, i London; Turk, 1962, in Jamaica). Some pneumo coccal capsular antigens are similar to some of those of $H$. influenzae (see Tunevall, 1952). There may welp be other sources of confusion.

We are grateful to Drs. P. S. Gardner and A. J. Wort an to a number of other colleagues for help in collecting. serum samples; to Miss Isabel Johnson, A.I.M.L.T., fo technical assistance; and to the Peel Medical Researci Trust for a grant towards expenses.

REFERENCES

Alexander, H. E. (1958). In Bacterial and Mycotic Infections of Mang edited by R. J. Dubos, 3rd ed., p. 474. Pitman, London.

Dawson, B., and Zinn乞mann, K. (1952). Brit. med. J., 1, 740. Good, P. G., Fousek, M. D., Grossman, M. F., and Boisvert, P. L을.
(1943). Yale J. Biol. Med., 15,913.

Keogh, E. V., North, E. A., and Warburton, M. F. (1947). Naturठ (Lond.), 160, 63.

,$- \stackrel{-}{-}(1948)$. Luid., 161, 687.

Masters, P. L., Brumfitt, W., Mendez, R. L., and Likar, M. (1958) Brit. med. J., 1, 1200.

May, J. R. (1958). In Recent Trends in Chronic Bronchitis, edited bo N. C. Oswald, pp. 178-179. Lloyd-Luke, London.

Pittman, M. (1931). J. exp. Med., 53, 471.

Rosenberg, E. Leidy, G., Jaffee, I., and Zamenhof, S. (1961). J. bio Chem., 236, 2841.

Sell, S. H. W. (1960). Amer. J. Dis. Child., 100, 7.

Tunevall, G. (1952). Acta path. microbiol. scand., 30, 203.

Turk, D. C. (1962). D.M Dissertation, University of Oxford. (1963). J. Hyg. (Lond.), 61, 247.

Wood, S. H., Buddingh, G. J., and Abberger, B. F. (1954). Pediatrics 13, 363. 